\title{
INCONGRUITY IN THE GOSPEL PARABLES
}

\author{
David Seccombe
}

\begin{abstract}
Summary
Evidence is given of deliberate use of incongruity and the outright bizarre in some of the gospel sayings and parables. This is sometimes smoothed away by translators and commentators, who appear uncomfortable with it. Yet it has the marks of being one of Jesus' characteristic teaching devices, the tendency of the transmission being to smooth out discordancies. With this in mind the parable of the leaven is re-examined, and it is argued that it contains three incongruities which strongly suggest its authenticity and could have made it a startling piece of communication for its original listeners. The results gained are employed to clear the way for a correct approach to the parable of the ten minas.
\end{abstract}

\section{Introduction}

'The student of the parables of Jesus may be confident that he stands upon a particularly firm historical foundation. The parables are a fragment of the original rock of tradition.'

With those words Joachim Jeremias began his classic exposition of the parables of Jesus. ${ }^{1}$ Writing at a time when form criticism was the strong influence in New Testament studies Jeremias sought to cleanse the parables of the influences of their use by the early church and recover the dominical original. He was confident that the accretions were superficial, easily identified and removed, and, as he deals with individual parables, it becomes clear that in his view the parables as we

1 Joachim Jeremias, The Parables of Jesus (London: SCM, 1970): 1-2. 
have them are essentially and for the most part the work of the master. 'We stand right before Jesus when reading his parables'.

Many would agree with this judgement. ${ }^{3}$ The individual style of the parables displays an original mind unparalleled before, during or after the time of Jesus, and gives us our most obvious access to the personality and teaching style of someone who never wrote anything that was preserved, yet who is as real and accessible to us through his parables as Shakespeare is through his plays (more so!).

With this in mind I wish first to draw attention to an unusual characteristic of some of the parables which is frequently overlooked or misunderstood, and which, because it is not appreciated as part of Jesus' genius as a teacher, is often a stumbling block to translators and interpreters. I refer to Jesus' frequent use of incongruity and sometimes the outright bizarre to catch his hearers' attention and impress his truth upon them. ${ }^{4}$ I wish then to look at the little considered parable of the yeast in the light of this contention, and finally to make a few comments on the parable of the ten minas.

That Jesus might sometimes be deliberately injecting a bizarre element into a parable first impressed itself on me through a study of the mustard seed (Mark 4:30-32 par.), so let me begin with this as an example. The kingdom of God is likened to a mustard seed which, Jesus says, is the smallest of all the seeds. This need not be pressed literalistically. The mustard seed was proverbial for something tiny. The point is that the kingdom begins with something quite tiny by comparison with what follows. Strangely, what follows is not that great: the largest plant in the vegetable garden. The smallest of the seeds commonly sown in the Galilean vegetable garden, grows to

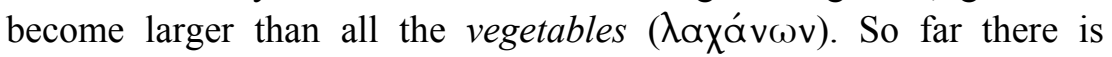

2 Jeremias, Parables, 12; similarly N. Perrin, Jesus and the Language of the Kingdom (Philadelphia: Fortress, 1976): 199, 'the parables are perhaps the most characteristic form of the speech of Jesus'.

3 Arland J. Hultgren, The Parables of Jesus (Grand Rapids: Eerdmans, 2002): 6-11, warns against claiming too great a uniqueness for Jesus' parables 'in the interests of asserting the superiority of Jesus over his contemporaries', but identifies six characteristics which, when combined, mark Jesus' parables as 'distinctive, even original and unique'.

4 Attention was drawn to this device by Norman A. Huffman, 'Atypical Features in the Parables of Jesus', JBL 97 (1978): 207-220. Klyne Snodgrass, Stories with Intent: A Comprehensive Guide to the Parables of Jesus (Grand Rapids: Eerdmans, 2008): 18, notes that although Jesus' parables depict normal life their frequent use of 'hyperbole and elements of surprise or improbability' sometimes make them 'pseudo realistic'. 
nothing out of the ordinary: despite its tiny seed the mustard plant overtakes all the other vegetables, becoming a shrub, three or four feet high. But then something odd happens. It makes great branches so that the birds of heaven can make nests in its shade. This does not sound like the mustard plant. The NIV says, 'it becomes the largest of the garden plants with such large branches that the birds of the air can perch in its shade'. Is there an attempt in this translation to lessen the impression of a great tree and so save Jesus' horticultural credibility? Similar attempts to save Jesus' credibility, and, in so doing, keep the kingdom in the vegetable garden are to be encountered among the commentators. David Wenham approvingly cites B. Matthews, who speaks of 'goldfinches and linnets coming in flocks to perch in this tree-like herb'. ${ }^{5}$ Oesterley thinks the point is that the mustard plant 'exceeds in growth all other plants of its kind' ${ }^{6}$ But surely what we see in the parable is the plant breaking out of its kind, for the tree with great branches which gives home to the birds of heaven (not just finches, but surely eagles and the like) is the great cedar of Lebanon which in Daniel 4 is a picture of Nebuchadnezzar's empire, and in Ezekiel 17:22-24 of Israel's future glorious kingdom. Many commentators admit this allusion, though it conflicts with Dodd's principle that in the parables 'all is true to nature and life'. ' Jeremias' good instinct makes it an exception to his general rule that scriptural allusion in the parables represents later reinterpretation. ${ }^{8}$ Crossan assigns the allusion to later development of the tradition: "When one starts a parable with a mustard seed one cannot end it with a tree, much less the great apocalyptic tree. ${ }^{9}$ But why not? What is not recognised is that Jesus may have deliberately introduced the incongruity into the parable both to catch the attention of his hearers, and to carry their thoughts to the Old Testament image. His kingdom begins as a tiny seed. But it grows - initially in a predicable manner - to become the

5 David Wenham, The Parables of Jesus: Pictures of Revolution (London: Hodder \& Stoughton, 1989): 54.

6 W. O. E. Oesterley, The Gospel Parables in the Light of Their Jewish Background (London: SPCK, 1936): 77. 'It is especially, we are told, gold-finches and thistle finches which seek shelter from rain and from the sun's rays in its branches'.

7 C. H. Dodd, The Parables of the Kingdom (London: Nisbet, 1936): 20. Nevertheless, even Dodd acknowledges as probably dominical the allusion to Daniel's and Ezekiel's great tree.

8 Jeremias, Parables, 32.

9 John Dominic Crossan, The Historical Jesus: The Life of a Jewish Mediterranean Peasant (HarperSanFrancisco, 1992): 277. 
queen of the vegetable garden. But then something reminiscent of Jack's beanstalk begins to happen: it puts out great branches. The initial impact of this on the hearers would be an inward query: 'Does Jesus know what he is talking about? This is not the mustard plant I know.' And in the very moment of querying their attention has been captured. But this, says the parable, is how the kingdom of God develops. And it is not a long step from this to see in the final image the great empire of the future, outstripping even the kingdom of Babylon, in which even the Gentile nations will find a home. Thus an incongruous element in the parable catches the listener's attention and carries it on to Jesus' intended meaning. This makes the parable more than a homely illustration. It becomes a memorable, attention catching piece of communication.

\section{Throughout the Tradition}

Even a superficial excursion through the images Jesus employs in his many parabolic 'one-liners' and parabolic images reveals how congenial to his communication style were incongruity, exaggeration and the bizarre. Categorising the references into their various sources shows that they are a feature of every layer of the tradition and therefore must certainly stem from Jesus.

Examples from Mark are the camel trying to get through the eye of a needle (10:25), cutting off an offending hand (9:43) and being cast into the sea with a millstone around your neck $(9: 42)$. There are others too which catch the attention, ${ }^{10}$ sometimes by exaggeration, sometimes by their violence, and sometimes by their incongruity - at least they would have once; the modern reader is desensitised by familiarity and the tendency to read 'religiously'.

In $\mathrm{Q}$ one is impressed by the extravagant image of raising one's cloak to receive a gift of grain 'good measure, pressed down, shaken together, running over' (Luke 6:38), the comic image of a blind person trying to lead another blind person (Luke 6:39) and many others. ${ }^{11}$

Special Luke gives us Jesus casting fire on the earth (12:49), and the vultures descending on Israel's dead corpse (17:37). Special Matthew assaults us with the image of throwing pearls before pigs and the

10 Also consider Mark $3: 35 ; 7: 27 ; 8: 33,34 ; 9: 35 ; 11: 23 ; 14: 24$.

11 Luke 6:29; 6:41; 7:28; 9:60; 11:23, 39; 11:44; 12:3; 13:30; 14:11, 26; Matt. 11:12. 
challenge to be as wise as serpents $(7: 6 ; 10: 16) .{ }^{12}$ John has Jesus challenging his hearers to destroy the temple (2:19), telling Nicodemus he must be born again (3:3), and the Jews that they must eat his flesh and drink his blood (6:53). ${ }^{13}$

Special Luke yields the least of these striking mini-parables, but we find bizarre elements in his larger parables. First we should notice a number of offensive comparisons. Jesus employs a Samaritan to model the quality of neighbourly love envisioned in the law (10:25-37). The lack of compassion on the part of the Levite and the priest and the helpfulness of a Samaritan are not beyond the bounds of possibility. But the Samaritan's offer to pay all further costs pushes us beyond the natural. Commentators tend to ignore this: 'All the detail surrounding the care given to the wounded man is entirely realistic and serves only to underline the extent of the Samaritan's love.'14 'In whose world would someone leave a blank cheque for the care of a stranger?' one is tempted to ask.

The a fortiori argument of the parable of the unjust judge speaks clearly enough: if the judge eventually responds to the widow's persistent request for justice how much more will God respond to the calls of his elect (18:1-8)? Yet the comparison displays an apparent irreverence which catches the attention. Who would risk likening God to an unjust judge? Why underline this (kpitìs tĩs ádikías)? The person who framed the comparison displays a reckless disregard for the sensibilities of the pious, and offends religious sentimentality. The parable maker appears more concerned with riveting the truth to the mind and memory than with sparing people's feelings. Recall Jesus' words to the man who asks leave to bury his father (Matt. 8:22; Luke 9:60).

The parable of the unjust steward (Luke 16:1-9) provides a further example. The debates over whether it is his master or Jesus who

\footnotetext{
12 Also 5:20?

13 I recall C. F. D. Moule saying once in a conversation that Jesus could never have said such a thing; it was far too offensive to Jewish sensibilities. For something similar see John 9:39.

14 Craig Blomberg, Interpreting the Parables (Downer's Grove: Intervarsity, 1990): 230. At the purely natural level one wonders whether Jesus' injunction to go and do likewise would be better heeded if the Samaritan's care was less extravagant. Perhaps there is some justification here for those who suspect the parable of a christological subcurrent. Snodgrass, Stories, 348, cites B. Gerhardsson as a modern defender of a christological reference.
} 
commends the steward's behaviour reveals the discomfort of some modern commentators with the parable's risky commendation of some shady business dealing. But should we not see the discomfit which the parable generates as intentional? Does it not force us into enquiry? Jesus' intent after all is an assault on the religious complacency of disciples, who, in the light of an impending catastrophe, which they confess to believing in, comfortably do nothing. Who better than a businessman, crooked or not, faced with imminent bankruptcy to model the resolute action Jesus wished in his followers?

\section{Deliberate Exaggeration}

Let us now note a few further examples of deliberate exaggeration in the parables. Most commentators are clear about its importance in the parable of the unmerciful servant (Matt. 18:23-35), though some think it is Matthew who has exaggerated the debt. ${ }^{15}$ Ten thousand talents was fifty times the yearly tribute of Galilee and Transjordan in $4 \mathrm{BC},{ }^{16}$ an impossible sum. Perkins thinks it would remind a Jewish audience of the fabled wealth of Persian kings. ${ }^{17}$ In any case it was certainly a sum which would arrest attention. If the intention is to seize the hearers' attention with an astronomical debt, it is a mistake to go searching for a realistic life setting. And if Matthew would employ such a device to highlight the impossible debt we owe to God, why not Jesus?

Exaggeration is a charge that has sometimes been levelled at Matthew, as though it were a literary fault. But does not the parable of the lost coin in the Special Luke collection evidence something similar (Luke 15:8-10)? I agree that Jesus reads human nature well when he recognises the disproportionate joy we often experience when we find something we have lost. But to call her friends and neighbours together for a celebration goes beyond the normal and might even have raised a laugh: 'Who in their right mind would throw a party for a lost coin?' There could have been real discomfort in the mental questions that might have followed: 'Is Jesus comparing these sinners to a lost coin?

15 E.g. F. W. Beare, The Gospel according to Matthew (San Francisco: Harper \& Row, 1981): 383 (tentatively).

16 Jeremias, Parables, 30

17 Pheme Perkins, Hearing the Parables of Jesus (Paulist: New York, 1981): 124. 
What really is their worth then? Would it be any joy to me that one repented? What would I be willing to do to facilitate such a thing?'

The Q parable of the mote and beam (Matt. 7:3-5) is voted pink'Sure sounds like Jesus' - by the Jesus Seminar. ${ }^{18}$ Put to mime by an open air communicator this kind of comic exaggeration could have convulsed an audience hearing it for the first time. Who would have failed to carry home the image, and wonder whether their own failures might not be quite a bit more serious than those of the one they have been wont to criticise?

We could multiply examples of deliberate use of the incongruous and bizarre. I conclude with one where failure to discern Jesus' technique has led to insipid translation, commentary and preaching, and make some preliminary comments on another which has caused commentators and preachers unnecessary disquiet.

\section{Parable of the Leaven}

The parable of the leaven (frequently misnamed the parable of the yeast) is twinned with the parable of the mustard seed in Matthew and Luke (Matt. 13:33; Luke 13:20-21). It is the smallest of Jesus' kingdom parables, and its meaning often taken to be so similar to its twin that it suffers in the partnership.

The kingdom of heaven is like leaven which a woman took and hid in three measures of meal until it was all leavened.

Perkins mistakenly equates leaven and yeast, as do many commentators and translators, and concludes that the point is the insignificant size of the yeast compared to the resulting bread. ${ }^{19}$ Concentrated yeast is a modern invention. Leaven was a lump of dough left over from the last bread making. ${ }^{20}$ The parable draws no attention to the size of the leaven, though it does to the flour. The point may lie elsewhere than a simple small-large comparison.

18 Robert W. Funk, Roy W. Hoover and the Jesus Seminar, The Five Gospels (New York: Macmillan, 1993): 153.

19 'The amount of yeast would seem to be insignificant. The ratio in a batch of bread I made yesterday, for example, was one part yeast to a hundred and twelve parts flour.' Perkins, Parables, 88.

20 Snodgrass, Stories, 231. 
So let us now savour the probable impact of Jesus likening the kingdom to leaven (or its action), for, as many writers note, leaven was a common metaphor for evil. ${ }^{21}$ Fermentation was understood as a process of putrefaction, which indeed it is. ${ }^{22} \mathrm{~A}$ small amount of evil insidiously corrupts whole persons and even societies. With an irreverent reapplication of similes Jesus may already have unbalanced his listeners. ${ }^{23}$ But then the agent of corruption-now become the essence of God's kingdom - is taken by a woman and hidden in three seahs of flour. 'Mixed into a large amount of flour', reads the NIV,

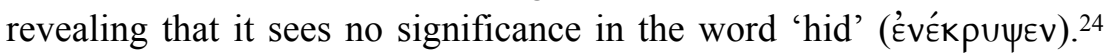
Blomberg too warns us not to over interpret this word and sees it as just a graphic way of describing the mixing process. ${ }^{25}$ But surely it is graphic in conjuring a picture not of mixing, but of hiding, which, given other teaching which explicitly addresses the kingdom's hiddenness, ${ }^{26}$ demands our attention. We must give Matthew's and Luke's words their due force; 27 if language means anything, what is being described here is not a woman making bread, but hiding leaven - despite the almost universal assumption of commentators.

A woman hides leaven in three seahs of flour. But who in their right mind would hide yeast in flour? The parable here makes an assault on the hearers' common sense, a second assault when one realises that three seahs is over twenty kilograms of flour, enough to feed one hundred people. Three seahs makes an ephah. An ephah could be about 21 litres, but possibly twice that amount. ${ }^{28}$ Understood as a bread making exercise this would feed the whole village, require more than

21 Snodgrass, Stories, 229-30, 233, gives instances of positive metaphorical uses, but admits that in most cases the connotations are negative. Elsewhere in the NT yeast is a symbol of evil.

22 Plutarch, Quaestiones Romanae 109 (289F). See Snodgrass, Stories, 229.

23 On this basis the Jesus Seminar votes this parable as undoubtedly dominical (red). Funk et al, Gospels, 195.

24 It is unclear whether the gospel of Thomas log. 96 used the image of hiding. It ignores the unusual quantity of flour.

25 Blomberg, Parables, 285.

26 In several parables it is inferred that an initial concealment is part of Jesus' deliberate strategy. E.g. 'For nothing is concealed (kpuпtóv) except that it may be made visible, nor is anything hidden ('́rтókpupov) but that it may come to light' (Mark 4:22).

27 So Snodgrass, Stories, 231.

28 Based on Josephus an ephah is estimated at 39 litres. A jar found at Qumran indicates 43-45 litres. Jars found near Jerusalem, however, support 21 litres (ISBE 4:1051). 
one woman to knead, and demand more oven space than any normal home could avail. It makes little sense to understand it as an obscure allusion to the three seahs Sarah prepared for the angelic visitors in Genesis $18: 6 ;{ }^{29}$ it is more likely that we are dealing with the family flour barrel. The different estimates of the size of an ephah judging from first-century evidence (see note 28) indicates perhaps that the ephah had come to describe, not an exact measure, but a large container of an approximate size. Jeremias sees the large amount of flour as a feature of the parable 'transcending the bounds of actuality', and meant to tell us 'that we have to do with divine reality', but thinks this touch has been added by Matthew and Luke. Does he betray an unwillingness that the parable should depart from Dodd's dictum, that in the parables 'all is true to nature and life'. ${ }^{30}$ But would those who transmitted the parable have dared to add something discordant to what otherwise is perfectly straightforward? The tendency of later (and modern) interpreters is rather the opposite: to smooth away such features. Why should these not be part of the original gem?

May I indulge a flight of exegetical fancy at this point? What sane woman would hide leaven in flour? Under what circumstances would anyone wish to hide leaven? Is this not bizarre? I am suggesting it is intentionally so, but a scenario nonetheless springs to mind. A woman is caught out at Passover time! All leaven was required to be removed from the house for the whole period of the feast of unleavened bread, on pain of excommunication. ${ }^{31}$ According to the Mishnah the house was to be searched to remove all traces! ${ }^{32}$ One imagines the visit of a Pharisee, and a lump of leaven (unmistakable smell) still sitting on the kitchen table. What to do? The flour barrel offers an answer. Such a scenario (I am not wishing to insist on it) could suggest the possibility of comedy. One need not be pedantic about the absence of water; with comedy the association of flour and leaven is sufficient to conjure a scene. We have seen cartoons where yeast and too much flour resulted

29 Elizabeth Walker, 'The Parable of the Leaven: A Sectarian Teaching and the Inclusion of Women', Union Seminary Quarterly Review 35 (1979-80): 99-109. The connection is well argued. The problem is finding any coherent meaning. A link between the slow fermentation process and the nine months of Sarah's pregnancy is impossibly obscure for the parable's hearers.

30 Jeremias, Parables, 147. See note 7, above.

31 Exod. 12:15-19; Deut. 16:2-4.

32 Mishnah Pesahim begins with instructions for searching for leaven (hametz) 'by the light of a lamp' on the eve of Passover. 
in dough overflowing the bowl, and then the kitchen table. A rabbi's visit, a barrel of flour with a lump of hidden yeast hastily thrust below the surface, and an anxious woman making polite conversation, have the makings of a comic scene.

The hiding of an agent of corruption and putrefaction (but now a principle of beneficial transformation) in a barrel of flour with the resulting transformation of its whole content easily suggests the transformation of the world which will be the final result of the kingdom message presently concealed in Jesus' parables, humble

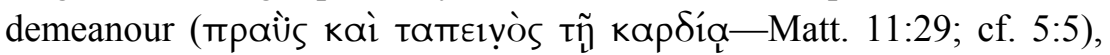
and peaceable mission (teaching versus the sword). We should not overlook that elsewhere on the lips of Jesus leaven is an image for the persuasive and pervasive effects of false teaching (Matt. 16:5-12), or of hypocrisy (Luke 12:1). ${ }^{33}$ Perhaps he saw a connection between these two. In reversing the moral polarity of the leaven symbol he points to the transforming power of his own teaching (and sincerity: life?) as the instrument which will bring about the kingdom. He also expresses absolute confidence in his strategy. Thus the tiniest of all the parables contains three incongruities that catch the listeners and entice them to ponder his meaning: in what manner is his strategy like leaven fermenting in dough, or false teaching/hypocrisy infecting individuals and societies? Is this why he is content to hide his lamp under a basket? Could there be power in his teaching that is little apparent, but will overcome evil and bring the kingdom of God?

\section{Parable of the Ten Minas}

If we apply the insights we have gained to Luke's parable of the ten minas (Luke 19:11-27) we quickly see how misplaced is the anguish felt by some commentators at the comparison between Jesus and Archelaus. ${ }^{34}$ The figure of Archelaus is unmistakable in the parable's description of the nobleman who had to go into a far country to receive his kingdom. Luke tells us Jesus spoke the parable as he was leaving

33 Luke could not have been unaware of the connection of ideas: leaven, hypocrisy, hiding, final revelation in 12:1-3 and hypocrisy, leaven, hiding in 13:10-20. Does this explain the odd placing of the healing of the crippled woman?

34 For a more detailed discussion of the parable see David Seccombe, The King of God's Kingdom: A Solution to the Puzzle of Jesus (Milton Keynes: Paternoster, 2011): 493-99. 
Jericho on his way to Jerusalem. Herod's winter palace, which Archelaus rebuilt after its destruction by fire, was likely visible to the implied first hearers of the parable. So the parable deliberately conjures the image of Archelaus. Yet Archelaus was so incompetent and brutal that even the Romans decided he was bad and sent him into exile. Pious sentiment recoils from likening Jesus and his kingdom to the antics of a first-century Saddam Hussein. So who but Jesus himself would have dared frame such a comparison? The parable is clearly dominical! And it must once have had considerable shock value, forcing listeners to ask themselves what Jesus could possibly mean.

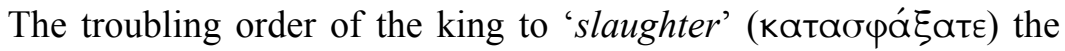
citizens who had agitated against him fits well with the picture of the angry Archelaus getting even with his detractors. Troubling it may be to the sensibilities of twenty-first-century readers, but it would probably have been relished by first-century listeners as part of a good story. How it should be read in terms of Messiah's dealings with his enemies is another matter. It is silly to apply it mechanically and literalistically. Better to see it goading the hearers to solemn inquiry: 'What might the King Messiah do to those who oppose his kingdom?'35

\section{Conclusion}

Three incongruities in the parable of the leaven, a shocking comparison in the parable of the ten minas, and bizarre elements in others are enough to warrant our acknowledging them as a characteristic, not of every parable, but common enough to recognise a personality and a distinctive teaching style. In conclusion I would claim firstly that identification of incongruity in a gospel parable, counter-intuitive as it is, may weigh as evidence of its dominical originality. Second, it is important that scholars and pastors be aware of this peculiarity and not make the error of insipid mistranslation, commentary and preaching. The Gospels attest that Jesus held the attention of tens of thousands in

35 Like the master who 'dichotomised' ( $\delta$ ıхотоци́бє1) the servant he caught out mistreating the other servants (Luke 12:46). There is no extant instance of a non-literal use of the term. More likely is it a story-teller's shocking image, calculated to capture attention: 'he will chop him in pieces'. (LXX Exod. 29:17 employs the word for the dismembering of a sacrifice, so it has a broader meaning than 'cut in two'.) Killing of slaves, though not unheard of, was extreme, especially in a Jewish context. 
the open air for long periods of time; he did not do it with limpid illustrations. No doubt there were many aspects to his art, and this, I suggest, was one of them. 